\title{
KESADARAN HUKUM DALAM BERLALU LINTAS SISWA SMK ZAIDAR YAHYA KECAMATAN RAMBAH
}

\author{
Ryan Prayogi ${ }^{1}$, Ilham Rahmawati ${ }^{2}$ \\ ${ }^{1}$ Universitas Pasir Pengaraian \\ Ryan.prayogi888@gmail.com \\ ${ }^{2}$ Universitas Pasir Pengaraian \\ Ilhamrahmawati4@gmail.com
}

\begin{abstract}
ABSTRAK
Dewasa ini bangsa Indonesia mengalami pertumbuhan angka penduduknya yang sangat pesat menggunakan kendaraan bermotor, terutama siswa SMK yang mengemudikan kendaraan bermotor tidak dengan sewajarnya baik menerobos lampu merah, tidak memiliki surat izin mengemudi, tidak membawa kelengkapan kendaraan seperti helm, spion dan kenalpot standar. Ini berdampak terhadap kesadaran hukum dalam berlalu lintas siswa SMK Zaidar Yahya. Maka tujuan dari penelitian untuk mengetahui tingkat kesadaran hukum siswa dalam berlalu lintas Pada Siswa SMK Zaidar Yahya. Sedangkan menggunakan metode penelitian kualitatif deskriptif dan teknik pengumpulan data ialah observasi, wawancara dan dokumentasi. Dari hasil penelitian bahwa tingkat kesadaran hukum berlalu lintas siswa SMK Zaidar Yahya tergolong cuku baik. Hal ini dibuktikan bahwa diantara siswa tersebut hanya semata-mata takut akan sanksi ketika razia kendaraan bermotor, tidak menggunakan kelengkapan saat berkendaraan seperti surat izin mengemudi, helm, spion dll. Oleh sebab itu berdampak dengan kurangnya kesadaran hukum dalam berlalu lintas siswa walaupun sudah diberi pengetahuan tentang lalu lintas, tetapi tetap saja masih ada juga siswa yang melakukan pelanggaran lalu lintas dan tidak menyadari akan keselamatan dan keamanannya dalam berkendaraan.
\end{abstract}

Kata kunci: Kesadaran Hukum; Lalu Lintas, Siswa

\begin{abstract}
Today, the Indonesian nation has experienced a very rapid population growth using motorized vehicles, especially vocational students who drive motorized vehicles that do not properly run red lights, do not have driving licenses, do not carry vehicle equipment such as helmets, mirrors and standard exhausts. This has an impact on legal awareness in the traffic of Zaidar Yahya Vocational School students. So the purpose of the study was to determine the level of legal awareness of students in traffic at SMK Zaidar Yahya students. While using descriptive qualitative research methods and data collection techniques are observation, interviews and documentation. From the results of the study that the level of traffic law awareness of the students of SMK Zaidar Yahya is quite good. This is proven by the fact that among these students are merely afraid of sanctions when raiding motorized vehicles, do not use equipment when driving such as driving licenses, helmets, mirrors etc. Therefore it has an impact on the lack of legal awareness in student traffic even though they have been given knowledge about
\end{abstract}




\section{Kesadaran Hukum Dalam Berlalu Lintas Siswa Smk Zaidar Yahya Kecamatan Rambah}

traffic, but still there are also students who commit traffic violations and are not aware of their safety and security in driving.

Keywords: Legal Awareness; Traffic, Students

\section{PENDAHULUAN}

Indonesia merupakan negara berkembang seiring dengan jumlah penduduk yang sangat banyak sebagai pengguna alat transportasi di setiap wilayahnya masing-masing. Pengguna kendaraan di Jakarta, Bandung, Medan, Surabaya dan Riau sudah semakin padat dengan bertambahnya transportasi darat dan udara setiap tahun yang tidak sebanding dengan jumlah penduduk dan ruas jalan. Transportasi adalah sebuah proses pindah, gerak, mengangkut dan mengalihkan dimana proses ini tidak bisa dilepaskan dari keperluan akan prasarana transportasi (jalan) untuk menjamin lancarnya proses perpindahan sesuai dengan waktu yang diinginkan. ${ }^{1}$ Trasnportasi yang semakin berkembang tentu dibarengi dengan semakin bertambah lalu lintas pengguna jalan yang mengakibatkan angka kecelakaan semakin bertambah. Oleh sebab itu, untuk mendukung pembangunan dan integritas bangsa perlu sebuah aturan dalam penegakan lalu lintas di Indonesia yang mendukung pasal 1 ayat 3 yang menyatakan bahwa "Negara Indonesia adalah negara hukum". ${ }^{2}$ Begitu juga dalam pasal 27 ayat 1 menyatakan bahwa "segala warga negara bersamaan kedudukannya di dalam hukum dan pemerintahan dan wajib menjunjung hukum dan pemerintahan itu dengan tidak ada kecualinya". ${ }^{3}$ Untuk itu demi memajukan kesejahteraan umum bagi masyarakat indonesia dalam hal ini dapat mewujudkan keselamatan, ketertiban, keamanan dan kelancaran dalam berlalu lintas, maka pemerintah memiliki peran strategis dalam mengatur sistem trasnportiasi nasional agar dapat menwujudkan disiplin dalam berlalu lintas berdasarkan Undang-Undang Nomor 22 Tahun 2009 Tentang Lalu Lintas dan Angkutan Jalan. ${ }^{4}$

Keberhasilan suatu Negara di dukung oleh masyarakat yang mencintai negaranya yang taat dan patuh terhadap hukum dan undang-undang yang berlaku dinegara kita khususnya undang-undang lalu lintas dan angkutan jalan. Kesadaran

\footnotetext{
${ }^{1}$ Miro, F. 2005. Perencanaan Transportasi untuk Mahasiswa, Perencana, dan Praktisi. Erlangga. Jakarta.

${ }^{2}$ Tim Visi Yustisia, 2014, UUD Negara Republik Indonesia 1945, Visimedia, Jakarta. Pasal 1 Ayat 3.

${ }^{3}$ Ibid, 2

${ }^{4}$ Undang-Undang No. 22 Tahun 2009 Tentang Lalu Lintas dan Angkutan Jalan, Yogyakarta: New Merah Putih.
}

20 ASANKA: Journal Of Social Sciencs and Education, 2 (1), 2021 


\section{Kesadaran Hukum Dalam Berlalu Lintas Siswa Smk Zaidar Yahya Kecamatan Rambah}

hukum adalah sikap yang perlu di tanamkan kepada seluruh warga Negara sebagai rasa tanggung jawab terhadap kelancaran roda pembangunan. ${ }^{5}$ Oleh karena itu, perlu usaha terencana dan terstruktur dari pemerintah dalam mewujudkan kesadaran hukum berlalu lintas masyarakat supaya mematuhi, memahami, mengerti dan menghargai sesama pengguna jalan dan kendaraan bermotor. Kesadaran hukum sebenarnya merupakan kesadaran atau nilai yang terdapat dalam diri manusia tentang hukum yang ada atau tentang hukum yang diharapkan ada. Sebenarnya yang ditekankan adalah nilai-nilai tentang fungsi hukum dan bukan suatu penilaian hukum terhadap kejadian-kejadian yang kongkrit dalam masyarakat yang bersangkutan. Maka kesadaran hukum yang rendah cenderung pada pelanggaran hukum dengan berbagai kemungkinan korban dan kerugian yang dideritanya, makin rendahnya kesadaran hukum banyak pelanggaran dan makin besar pula korbannya. ${ }^{6}$

Kesadaran hukum adalah kesadaran yang terdapat di dalam diri manusia tentang hukum yang ada atau tentang hukum yang diharapkan ada. ${ }^{7}$ Sehingga kesadaran hukum mampu mengangkat nilai-nilai dari fungsi hukum dalam diri manusia itu sendiri yang mentaati setiap hukum yang berlaku tanpa melakukan penilaian hukum terhadap dirinya sendiri sebagai bentuk pembenaran yang taat atau sadar hukum. Oleh sebab kesadaran hukum secara signifikan perlu kita tanamkan dalam diri masyarakat sebagai tanggung jawab bersama dalam mewujudkan pemerintahan yang baik (good governance) dalam berlalu lintas. Sehingga masyarakat sebagai pengguna jalan sadar akan pentingnya memahami, mengerti dan mentaati peraturan berlalu lintas.

Dewasa sekarang ini permasalahan yang dihadapi akibat dampak pertambahan penduduk dan selaku pengguna jalan ialah lalu lintas. Semakin banyaknya sekarang ini masyarakat sebagai pengguna kendaraan bermotor seperti mobil , motor dan pengguna alat trasportasi lainya. Meningkatnya volume kendaraan yang dibarengi terbatasnya penambahan ruas jalan raya sebagai penyebab masalah lalu lintas yang dewasa ini hampir disetiap wilayah. Akan tetapi kepatuhan hukum masyarakat terhadap etika berlalu lintas dapat dikatakan

\footnotetext{
${ }^{5}$ Soejono Soekanto, Kesadaran Hukum dan Kepatuhan Hukum, Edisi Pertama, (Jakarta: Rajawali, 1982), hlm. 182.

${ }^{6}$ Sanusi, Ahmad. 1984. Masalah Kesadaran Hukum Dalam Masyarakat Indonesia Dewasa Ini. Jakarta: Bina Cipta.

${ }^{7}$ Ibid, 5 .
} 


\section{Kesadaran Hukum Dalam Berlalu Lintas Siswa Smk Zaidar Yahya Kecamatan Rambah}

masih rendah. ${ }^{8}$ Hal ini dapat kita lihat di kehidupan sehari-hari banyak pengguna jalan yang menggunakan kendaraan bermotor yang tidak sesuai dengan kelengkapan kendaraannya seperti helm, spion, lampu, surat izin mengemudi, dan dalam berkendaraan ada yang menerobos lampu merah, menggunakan gawai saat berkendara serta ugal-ugalan dalam berkendaraan. Masyarakat yang taat atau patuh terhadap hukum menyadari betapa pentingnya keselamatan, ketertiban dan keamanan sesama pengguna jalan. Hal ini akan menjadi sebuah jaminan akan terselenggaranya aktifitas dalam berlalu lintas yang kondusif bila setiap warga Negara memiliki kesadaran hukum dalam berlalu lintas.

Pemerintah memiliki peran penting dalam meningkatkan kesadaran hukum berlalu lintas khususnya lembaga pendidikan formal baik ditingkat SD, SMP dan SMA/SMK perlu dibimbing dalam pengetahuan tentang hukum berlalu lintas agar mempunyai sikap dan etika yang baik mematuhi kaidah-kaidah hukum dalam berlalu lintas sesuai undang-undang lalu lintas dan angkutan jalan. Kesadaran peserta didik terhadap lalu lintas merupakan faktor penting yang perlu ditanamkan sikap disiplin dan tanggung jawab atas keselamatan, keamanan dan ketertiban dalam berlalu lintas. Oleh sebab itu siswa harus dibekali pengetahuan tentang peraturan lalu lintas dan anggkutan jalan. Rata-rata kecelakaan sepeda motor terjadi pada peserta didik yakni siswa SMA/SMK sederajat selaku pengguna jalan yang secara umur bisa memiliki surat izin mengemudi (SIM). Tetapi pada kenyataannya bahwa orang tua siswa cenderung mengizinkan anaknya menggunakan kendaraan sendiri menuju ke sekolah dan jarang mengawasi dan mengarahkan anaknya untuk menggunakan kelengkapan berkendara sebelum berangkat menuju sekolah.

Masalah dalam berlalu lintas sekarang ini di wilayah hukum Kabupaten Rokan Hulu sangat cukup mencemaskan khususnya di kota Pasir Pengaraian sebagai Ibu Kota Kabupaten Rokan Hulu setiap tahunnya terjadi pelanggaran lalu lintas yang dilakukan oleh masyarakat begitu juga dengan siswa sekolah yang lebih dari 700 kasus di tahun 2019 pelanggaran lalu lintas meliputi surat kendaraan yang tidak ada, tidak memakai helm, spion dan menerobos lampu merah sesuai data Polres Rokan Hulu. Berdasarkan data diatas bahwa kesadaran hukum peserta didik masih berada pada kesadaran hukum yang rendah, hal ini

\footnotetext{
${ }^{8}$ Safitri, S., \& Rahman, T. (2013). Tingkat Kepatuhan Hukum Siswa SMA Kartika Iv-3 Surabaya Terhadap Etika Berlalu Lintas Menurut Tentang Lalu Lintas Dan Angkutan Jalan. Kajian Moral Dan Kewarganegaraan, 3(1), 485-499.
}

22 ASANKA: Journal Of Social Sciencs and Education, 2 (1), 2021 


\section{Kesadaran Hukum Dalam Berlalu Lintas Siswa Smk Zaidar Yahya Kecamatan Rambah}

dibuktikan bahwa pelanggaran lalu lintas oleh peserta didik sebagai pengguna kendaraan bermotor terjadi menerobos traffic light, pengguna tidak memakai perlengkapan berkendaraan seperti helm, spion, SIM dan kenalpot tidak standar dalam menggunakan jalan raya. Sebagaian besar peserta didik tentu belum memahami peraturan lalu lintas sesuai undang-undang no 22 tahun 2009 tentang lalu lintas dan angkutan jalan. ${ }^{9}$ Dari hasil observasi awal ditemukan bahwa ratarata pelanggaran lalu lintas yang dilakukan oleh siswa ialah tidak menggunakan helm, spion, SIM dan melawan arus serta menerobos lampu merah traffic light. Sehingga siswa yang melanggar peraturan lalu lintas tidak menyadari bahwa jika mereka tidak melengkapi kendaraannya dapat membahayakan keselamatan, keamanan dan kertetiban sesama pengguna jalan raya. Berdasarkan fenomena tersebut peneliti tertarik melakukan penelitian di SMK Zaidar Yahya Kecamatan Rambah. Tujuan penelitian tersebut untuk mengetahui tingkat Kesadaran Hukum Berlalu Lintas Pada Siswa SMK Zaidar Yahya.

\section{METODE PENELITIAN}

Penelitian ini menggunakan metode penelitian kualitatif. Penelitian kualitatif adalah penelitian yang dilakukan untuk memahami fenomena tentang apa yang dialami oleh subjek penelitian yang disesuaikan dengan masalah yang akan diteliti guna untuk mendapatkan data dan informasi dalam penelitian ini. Metode penelitian juga disebut penelitian naturalistik karena penelitiannya dilakukan pada kondisi yang alamiah (natural setting). ${ }^{10}$ Sehingga metode penelitian tersebut menghasilkan data deskriptif berupa kata-kata tertulis atau lisan dari orang-orang dan perilaku yang diamati. ${ }^{11}$ Dari penggunaan metode kualitatif tersebut bisa memperoleh penemuan-penemuan yang tidak terduga sebelumnya dan bisa mewakili fenomena yang tampak. Lokasi penelitian ini dilakukan di SMK Zaidar Yahya Kecamatan Rambah Kabupaten Rokan Hulu, pemilihan lokasi tersebut dilakukan secara purposive (sengaja) berdasarkan kriteria atau pertimbangan tertentu dalam penelitian ini dengan maksud agar dapat mendekripsikan dan menginterpretasikan data dalam keadaan atau peristiwa sebagaimana adanya, sehingga sifat mengungkap fakta. Sedangkan teknik

\footnotetext{
${ }^{9}$ Ibid, 4.

${ }^{10}$ Sugiyono (2017). Metode Penelitian Kualitatif: Untuk Penelitian Yang Bersifat: Eksploratif, Enterpretif, Interaktif, dan Konstruktif. Bandung: Alfabeta.

11 Moleong, L.J. (2011). Metodologi Penelitian Kualitatif Edisi Revisi. Bandung: PT. Remaja Rosdakarya.
} 


\section{Kesadaran Hukum Dalam Berlalu Lintas Siswa Smk Zaidar Yahya Kecamatan Rambah}

pengumpulan data menggunakan teknik observasi, wawancara dan dokumentasi.

Dari ketiga teknik tersebut dijabarkan sebagai berikut :

1. Observasi

Observasi diartikan sebagai pengamatan dan pencatatan secara sistematik terhadap segala yang tampak dan objek penelitian. ${ }^{12}$ Metode observasi yang digunakan untuk mengumpulkan data sesuai fokus penelitian yang dilaksanakan di SMK Zaidar Yahya Kecamatan Rambah Kabupaten Rokan Hulu.

2. Wawancara

Metode yang digunakan dalam penelitian ini wawancara. Metode Wawancara atau interview merupakan proses memperoleh keterangan untuk tujuan penelitian dengan cara tanya jawab sambil bertatap muka dengan pihak yang bersangkutan. ${ }^{13}$ Metode wawancara digunakan sebagai pedoman melakukan penelitian dalam mewawancarai siswa SMK Zaidar Yahya Kecamatan Rambah Kabupaten Rokan Hulu.

3. Dokumentasi

Pada penelitian ini menggunakan metode dokumentasi sebagai data pendukung dalam penelitian. Metode dokumentasi adalah metode yang digunakan untuk mencari data mengenai hal-hal atau variabel-variabel yang berupa catatan, transkip, buku , surat kabar, agenda atau lain sebagainya. ${ }^{14}$ Oleh karena itu, dengan menggunakan teknik dokumentasi dapat mempermudah peneliti dalam mencari informasi pendukung di SMK Zaidar Yahya.

Teknik Analisis Data dalam Penelitian ini terdapat tiga alur kegiatan yakni : Pengumpulan data/ Reduksi data, Display data dan Penarikan kesimpulan/Verifikasi data". ${ }^{15}$ Dari ketiga alur kegiatan tersebut pemaknaan dari data dapat dilakukan apabila data yang dikumpulkan/diperoleh atas dasar kedalaman dari fakta lapangan. Setelah dilaksanakan analisis data diharapkan dapat menemukan dan mendeskripsikan data secara utuh dan menyeluruh mengenai kesadara hukum dalam berlalu lintas siswa SMK Zaidar Yahya Kecamatan Rambah.

\footnotetext{
${ }^{12}$ S. Margono, Metodologi Penelitian Pendidikan, (Jakarta: Rineka Cipta, Cet. V, 2005), 159.

${ }^{13}$ Nasution, Metodologi Research Penelitian Ilmiah, (Jakarta: Budi Aksara, 2002), 113.

${ }^{14}$ Suharsimi Arikunto, Prosedur Penelitian, (Jakarta: Rineka Cipta, 1993), 20.

15 Miles \& Huberman. (2007). Analisis Data Kualitatif Buku Sumber Tentang Metode-Motode Baru. Jakarta: Universitas Indoneisa Press.
}

24 ASANKA: Journal Of Social Sciencs and Education, 2 (1), 2021 


\section{HASIL DAN PEMBAHASAN}

\section{Tingkat Kesadaran Hukum Berlalu Lintas Pada Siswa SMK Zaidar} Yahya

a. Pengetahuan Siswa dalam Peraturan Lalu Lintas

Berdasarkan dari hasil wawancara penelitian terhadap kepala sekolah SMK Zaidar Yahya (S) bahwa Kesadaran hukum itu secara sadar seseorang mengetahui mengenai segala isi dari hukum tertentu yang baik mengenai hak maupun kewajiban seseorang. Sehingga SMK Zaidar Yahya sudah mulai menerapkan peraturan dalam pengguna kendaraan bermotor disekolah dengan membawa helm, teratur dalam memarkirkan kedaraan kedalam sekolah, tidak dibenarkan memakai knalpot yang tidak standar kendaraan. Begitu juga dari pihak Kepolisian Sektor Rambah juga sudah melaksanakan sosialisasi police goes to school tentang bagaimana siswa memahami peraturan lalu lintas dan pengguna jalan raya.

Dari hasil wawancara peneliti kepada siswa SMK Zaidar Yahya mayoritas pengetahuan siswa tergolong masih rendah terhadap pengetahuan tentang peraturan-peraturan berlalu lintas dan UndangUndang No 22 Tahun 2009 Tentang Lalu Lintas dan Angkutan Jalan. Karena tidak semua siswa yang mengikuti sosialisasi terhadap lalu lintas, siswa juga kurang mengetahui tata cara menggunakan kendaraan bermotor yang baik dan benar, dan kurang memahami kelengkapan yang digunakan sebelum berkendaraan. Serta dari beberapa pertanyaan wawancara seputar rambu-rambu lalu lintas yang diajukan peneliti dapat di jawab oleh siswa dengan benar. Dapat disimpulkan bahwa pengetahuan siswa tentang peraturan lalu lintas baik yang mengikuti dan tidak mengikuti sosialisasi program police to school dari Kepolisian Sektor Rambah tersebut belum memberikan dampak nilai positif bagi siswa, karena siswa belum memahami kesadaran hukum dalam berlalu lintas. Begitu juga siswa kurang memahami bagaimana pentingnya keselamatan berkendaraan di jalan raya. Sehingga kesadaran dalam berkendaan tidak dibarengi dengan pengetahuan yang cukup terhadap aturan lalu lintas yang mengakibatkan banyak terjadi angka kecelakaan di wilayah kecamatan rambah. 
b. Pemahaman Dan Kesadaran Hukum Siswa dalam Peraturan Lalu Lintas.

Berdasarkan hasil wawancara peneliti yang dilakukan kepada kepala sekolah SMK Zaidar Yahya bahwa pemahaman siswa terhadap peraturan lalu lintas tergolong cukup baik. Dari penuturannya bahwa siswa dibekali edukasi tentang peraturan lalu lintas baik dari guru, pemerintah dan kepolisian sektor rambah melalui sosialisasi tentang keselamatan dalam berkendaraan, begitu juga disekolah sudah diterapkan bahwa ketika membawa kendaran kesekolah harus sesuai syarat-syarat berkendara memakai Helm, Spion, Knalpot Standar dan memarkirkan, merapikan kendaraan sesuai tempat yang sudah ditentukan. Sehingga secara tidak langsung sekolah telah memberikan edukasi dalam kesadarah hukum berlalu lintas siswa.

Begitu juga hasil wawancara peneliti terhadap beberapa siswa di SMK Zaidar Yahya, pemahaman siswa terhadap peraturan-peraturan berlalu lintas tergolong cukup baik, dari beberapa pertanyaan yang diajukan peneliti tentang pemahaman dalam peraturan lalu lintas baik mengenai rambu-rambu, surat izin mengemudi, surat tanda kendaraan bermotor masih tergolong baik dan pertanyaan dalam tata cara berkendaran siswa selama ini cukup baik, serta mengenai keselamatan dalam berkendaraan juga bisa dijawab dengan baik dan benar. Tetapi dilihat dari hasil wawancara tentang kesadaran hukum siswa yang dilakukan peneliti masih banyak siswa yang tidak memahami dan menyadari pentingnya akan keselamatan dalam berkendaraan, dari penuturan siswa banyak yang tidak mengetahui batas kecepatan maksimum dalam berkendaraan, sering terburu-buru ketika berangkat ke sekolah, sering lupa menggunakan kelengkapan kendaraan seperti tidak memakai helm, tidak membawa surat izin mengemudi, surat tanda kendaraan bermotor, tidak memakai spion, tidak menggunakan knalpot standar, melawan arus, menerobos lampu merah, dan ada yang bertiga saat berkendaraan. Oleh karena itu, dapat kita simpulkan bahwa dari kesadaran hukum berlalu lintas siswa masih tergolong cukup baik dan hasil penelitian dari pemahamannya sudah cukup baik.

Maka dari hasil penelitian ini betapa pentingnya kesadaran hukum siswa dalam berlalu lintas, sebagai warga Negara yang baik, sudah sepatutnya siswa 


\section{Kesadaran Hukum Dalam Berlalu Lintas Siswa Smk Zaidar Yahya Kecamatan Rambah}

dibekali edukasi sejak dini mengenai peraturan lalu lintas. Edukasi kesadaran hukum berlalu lintas dapat meminimalisir angka kecelakaan dan juga pelanggaran lalu lintas yang dilakukan oleh siswa, dari pemahaman tersebut maka sangat berdampak akan ketertiban, keamanan, dan keselamatan dalam berlalu lintas bagi siswa maupun masyarakat selaku pengguna jalan raya. Sehingga siswa dapat memahami pentingnya kesadaran hukum berlalu lintas dan menjadi pelopor keselamatan berlalu lintas. Kesadaran hukum sebenarnya kesadaran atau nilainilai yang terdapat didalam diri manusia tentang hukum yang ada atau tentang hukum yang diharapkan ada. ${ }^{16}$ Maka nilai-nilai kebaikan dalam berlalu lintas yang dipahami oleh siswa SMK Zaidar Yahya dapat memberikan contoh kedepan bagi siswa yang lainnya akan pentingnya mematuhi akan peraturan lalu lintas. Jadi menurut hemat peneliti sebaiknya pemerintah, pendidikan formal dan kepolisian bersinergi membangun kesadaran hukum dalam berlalu lintas warga Negara untuk mengikuti peraturan-peraturan lalu lintas dan juga menjadikan nilainilai kesadaran hukum dalam berlalu lintas sebagai nilai positif dalam berkendaraan sebagai tanggung jawab pengguna jalan khususnya siswa. Kesadaran hukum siswa dalam berlalu lintas dan memahami peraturan lalu lintas merupakan faktor penting bagi siswa selaku pengguna jalan untuk menjaga keselamatan dan keamanan siswa dalam berlalu lintas.

Oleh karena itu, masalah kesadaran hukum timbul apabila nilai-nilai yang akan diwujudkan dalam peraturan hukum merupakan nilai-nilai yang baru, hal ini sebagai konsekuensi logis dari meluasnya fungsi hukum yang tidak sekedar hanya merekam kembali pola-pola tingkah laku yang sudah ada didalam masyarakat. Ia justru menjadi sarana penyalur kebijaksanaan- kebijaksanaan pemerintah, sehingga terbuka kemungkinan akan muncul keadaan-keadaan baru untuk merubah sesuatu yang sudah ada. ${ }^{17}$ Dari konsep diatas dapat kita pahami bahwa kesadaran hukum yang terjadi dikalangan masyarakat maupun siswa SMK Sederajat selaku pengguna kendaraan bermotor di jalan raya itu terjadi jika peraturan hukum berlalu lintas dengan sungguh ditegakan dan dijalankan sebagaimana mestinya. Sehingga dapat mengurangi masalah kesadaran hukum dan angka kecelakaan di masyarakat.

Oleh sebab itu, kesadaran hukum berlalu lintas terdapat faktor-faktor yang mempengaruhinya ialah : Pertama, Pengetahuan akan Kesadaran Hukum, Kedua,

\footnotetext{
${ }^{16}$ Ibid, 5.

${ }^{17}$ Satjipto Rahardjo, Hukum dan Perubahan Sosial, (Bandun: Alumni, 1979), hlm. 144.
} 


\section{Kesadaran Hukum Dalam Berlalu Lintas Siswa Smk Zaidar Yahya Kecamatan Rambah}

Pengakuan dari Ketentuan Hukum, Ketiga, Penghargaan dari Ketentuan Hukum, Keempat Penataan terhadap Ketentuan Hukum dan Kelima, Ketaatan/ Kepatuhan Hukum masyarakat. ${ }^{18}$ Berdasarkan faktor tersebut tentu paling utama dalam terciptanya pelaksanaan hukum berlalu lintas dikalangan siswa SMK, siswa harus dibekali pengetahuan dan Pengakuan terhadap ketentuan hukum. Pelaksanaan hukum selalu melibatkan manusia dan tingkah lakunya. Hukum tidak bisa terlaksana dengan sendirinya, artinya hukum tidak mampu untuk mewujudkan sendiri janji serta kehendak yang tercantum dalam peraturan hukum itu. ${ }^{19}$ Oleh sebab itu, pemerintah dan masyarakat bersinergi dalam menjalankan peraturan hukum lalu lintas supaya mengurangi angka kecelakaan setiap tahunnya dan juga memberikan sosiasisasi berkelanjutan keseluruh pendidikan formal dan informal. Sehingga generasi muda bangsa Indonesia dapat menjaga akan keselamatan, keamanan dan keterbiban dalam menggunakan jalan raya sebagai kebutuhan sehari-hari.

Senada dengan pendapat Soerjono Soekanto ada tiga faktor yang dapat mempengaruhi masyarakat mematuhi hukum ialah Compliance, Identification, Internalization..$^{20}$ Dari ketiga faktor tersebut yang sesuai dengan kesadaran hukum adalah Compliance sebagai bentuk kepatuhan hukum yang didasarkan harapan akan sesuatu imbalan dan usaha untuk menghindar dari hukuman yang dijatuhkan ketika melanggar peraturan yang ada. Hal ini dilihat dari hasil observasi, wawancara dan dokumentasi tersebut dapat disimpulkan bahwa siswa SMK Zaidar Yahya memiliki kesadaran hukum dalam berlalu lintas tergolong masih cukup baik, dari beberapa pertanyaan baik dari pengetahuan, pemahaman, dan kesadaran hukum siswa dapat dijawab dengan cukup baik dan dari beberapa siswa pernah melakukan pelanggaran hukum berlalu lintas seperti siswa banyak yang tidak mengetahui batas kecepatan maksimum dalam berkendaraan, sering terburuburu ketika berangkat ke sekolah, sering lupa menggunakan kelengkapan kendaraan seperti tidak memakai helm, tidak membawa surat izin mengemudi, surat tanda kendaraan bermotor, tidak memakai spion, tidak menggunakan knalpot standar, melawan arus, menerobos lampu merah, dan ada yang bertiga saat berkendaraan. Oleh sebab itu disini jelas bahwa diantara siswa tersebut

\footnotetext{
18 Mariani, 2019. Kesadaran Hukum Peserta Didik Dalam Berlalu Lintas, Jurnal Phinisi Integration Review. Vol 2(2). Hal 284.

${ }^{19}$ Ishaq, 2016. Dasar-Dasar Ilmu Hukum. Jakarta: Sinar Grafika.

${ }^{20}$ Soerjono Soekanto, 1982. Kesadaran Hukum \& Kepatuhan Hukum. Jakarta: CV Rajawali.

28 ASANKA: Journal Of Social Sciencs and Education, 2 (1), 2021
} 
hanya semata-mata takut akan sanksi ketika razia kendaraan bermotor oleh Satlantas Kepolisian Sektor Rambah. Dari hasil penelitian ini jelas kurangnya kesadaran hukum siswa dalam berlalu lintas walaupun secara pengetahuan tentang lalu lintas sudah diberikan tetap saja masih ada juga siswa yang melakukan pelanggaran lalu lintas dan tidak menyadari akan keselamatan dan keamanannya dalam berkendaraan.

\section{PENUTUP}

Berdasarkan hasil observasi, wawancara dan dokumentasi tersebut dapat peneliti ambil kesimpulkan bahwa siswa SMK Zaidar Yahya memiliki kesadaran hukum dalam berlalu lintas tergolong masih cukup baik, dari beberapa pertanyaan baik dari pengetahuan, pemahaman, dan kesadaran hukum siswa dapat dijawab dengan cukup baik dan dari beberapa siswa pernah melakukan pelanggaran hukum berlalu lintas seperti siswa banyak yang tidak mengetahui batas kecepatan maksimum dalam berkendaraan, sering terburu-buru ketika berangkat ke sekolah, sering lupa menggunakan kelengkapan kendaraan seperti tidak memakai helm, tidak membawa surat izin mengemudi, surat tanda kendaraan bermotor, tidak memakai spion, tidak menggunakan knalpot standar, melawan arus, menerobos lampu merah, dan ada yang bertiga saat berkendaraan. Oleh sebab itu disini jelas bahwa diantara siswa tersebut hanya semata-mata takut akan sanksi ketika razia kendaraan bermotor oleh Satlantas Kepolisian Sektor Rambah. Dari hasil penelitian ini jelas kurangnya kesadaran hukum siswa dalam berlalu lintas walaupun secara pengetahuan tentang lalu lintas sudah diberikan tetap saja masih ada juga siswa yang melakukan pelanggaran lalu lintas dan tidak menyadari akan keselamatan dan keamanannya dalam berkendaraan. Maka menurut peneliti ada beberapa saran sebagai berikut: pertama peneliti berharap siswa dapat meningkatkan kesadaran hukum dalam berlalu lintas, karena hal ini bukan hanya berkaitan dengan pribadi siswa tetapi juga berkaitan dengan masyarakat selaku pengguna jalan raya. Kedua siswa harus lebih mematuhi peraturan berlalu lintas yang berlaku bukan hanya sekedar terhidar dari sanksi tetapi lebih menanamkan dari diri sendiri bahwa kesadaran hukum tersebut merupakan bagian penting sebagai kewajiban dalam berkendaraan, dan yang terakhir demi tercapainya tujuan untuk meningkatkan kesadaran hukum siswa dalam berlalu lintas diharapkan masyarakat dapat berperan aktif dalam mematuhi peraturan hukum tentang lalu 
lintas agar dapat terciptanya keselamatan, kenyamanan, dan ketertiban dalam berkendaraan.

\section{DAFTAR PUSTAKA}

Ishaq. (2016). Dasar-Dasar Ilmu Hukum. Jakarta: Sinar Grafika.

Margono, S. (2005). Metodologi Penelitian Pendidikan, Jakarta: Rineka Cipta, Cetakan Ke- V, Hal 159.

Mariani. (2019). Kesadaran Hukum Peserta Didik Dalam Berlalu Lintas, Jurnal Phinisi Integration Review. Vol 2(2). Hal 284.

Miles \& Huberman. (2007). Analisis Data Kualitatif Buku Sumber Tentang Metode-Motode Baru. Jakarta: Universitas Indoneisa Press.

Miro, F. (2005). Perencanaan Transportasi Untuk Mahasiswa, Perencana, Dan Praktisi. Erlangga. Jakarta.

Moleong, L.J. (2011). Metodologi Penelitian Kualitatif Edisi Revisi. Bandung: PT. Remaja Rosdakarya.

Nasution. (2002). Metodologi Research Penelitian Ilmiah. Jakarta: Budi Aksara, Hal 113.

Safitri, S., \& Rahman, T. (2013). Tingkat Kepatuhan Hukum Siswa SMA Kartika IV-3 Surabaya Terhadap Etika Berlalu Lintas Menurut Tentang Lalu Lintas Dan Angkutan Jalan. Kajian Moral Dan Kewarganegaraan, 3(1), Hal 485-499.

Sanusi, A. (1984). Masalah Kesadaran Hukum dalam Masyarakat Indonesia Dewasa ini. Jakarta: Bina Cipta.

Satjipto, R. (1979). Hukum dan Perubahan Sosial. Bandung: Alumni, Hal. 144.

Soejono, S. (1982). Kesadaran Hukum dan Kepatuhan Hukum, Edisi Pertama. Jakarta: Rajawali, hlm. 182.

Sugiyono (2017). Metode Penelitian Kualitatif: Untuk Penelitian Yang Bersifat: Eksploratif, Enterpretif, Interaktif, dan Konstruktif. Bandung: Alfabeta

Suharsimi, A. (1993). Prosedur Penelitian. Jakarta: Rineka Cipta, Hal 20.

Tim Visi Yustisia. (2014). UUD Negara Republik Indonesia 1945. Visimedia, Jakarta.

Undang-Undang No. 22 Tahun 2009 Tentang Lalu Lintas dan Angkutan Jalan. Yogyakarta: New Merah Putih. 